Johan L. Tønnesson

Professor, Institutt for lingvistiske og nordiske studier, Universitetet i Oslo Kjell Lars Berge

Professor, Institutt for lingvistiske og nordiske studier, Universitetet i Oslo

\title{
Redaksjonelt:
}

\section{Forskningen om sakens prosa}

Hvorfor enda et nytt tidsskrift? I Sverige og Norge, til dels også i resten av Norden, har det gjennom 15-20 års tid blitt drevet en ganske omfattende akademisk virksomhet som har forstått seg selv som sakprosaforskning. Mens den norske aktiviteten i begynnelsen tok mål av seg til å fylle et tomrom skapt av litteraturforskningens prioritering av det som i kulturen oppfattes som skjønnlitterære tekster (Eriksen 1995), sprang svenskenes sakprosaforskning ut av en tverrfaglig forskningstradisjon hvor man var særlig opptatt av sakprosatekstenes sosiale rolle og forankring (Svensson m.fl. 1995). I begge land var det historiske perspektivet sterkt til stede fra første øyeblikk. Det ble skrevet sakprosahistorie med hovedvekt på 1800- og 1900-tallet, men også med blikk inn i det turbulente 1700-tallet. I Norge publiserte man et tobinds verk med den lett polemiske tittelen Norsk litteraturhistorie (Eriksen og Johnsen (red.) 1998a og 1998b). En annen hovedutgivelse var Ottar Grepstads Det littercere skattkammer. Sakprosaens teori og retorikk (1997). Begge disse utgivelsene er først og fremst oversiktsverk. Svenskenes publikasjoner bar sterkere preg av å være teoretisk velinformerte og grundige enkeltstudier av en rekke litterære og funksjonelle sjangere. Foruten en omfattende rapportserie ble det i 2001 utgitt en bok med "sjutton fallstudier", dvs. eksempler på tekstanalyser (Melander \& Olsson, red.), og i 2003 en bok om teoretiske perspektiver på sakprosa (Englund og Ledin, red.).

I 2000 ble Prosjektmiljøet Norsk sakprosa etablert ved Universitetet i Oslo. Ambisjonen var å bygge et varig fagmiljø på et solid teoretisk fundament (Berge 2001), og det ble i løpet av tre år gitt ut en rekke monografier og konferanserapporter i en egen skriftserie. Tidsskriftet Sakprosa er dels å anse som en utvidet videreføring av denne skriftserien. Med dagens teknologi kan vi publisere alt fra avhandlinger til korte notiser innen en og samme tidsskriftramme. Tidsskriftet kan dermed dels også betraktes som en oppfølging av den svenske rapportserien ${ }^{1}$ og av årbokserien fra det første norske sakprosaprosjektet (Johnsen (red.) 1995, 1996 og $1997^{2}$ ).

Vi kan slå fast at den nordiske, især den svenske og norske, sakprosaforskningen de siste ti årene har utviklet teoretiske og analytiske redskaper som gjør det rimelig å karakterisere den som et eget fag- og forskningsområde. Samtidig har sakprosaforskningen styrket sin rolle i skoleverket og i offentligheten. 
Dermed er det også betimelig å opprette et felles, nordisk tidsskrift for sakprosaforskning.

Hva innebærer så begrepet sakprosa? Hvilke er sakprosaforskningens perspektiver og teoretiske rammer? Hva slags tekster studeres? Hvilken utvikling kan vi tenke oss? Det er temaer for denne korte velkomstartikkelen.

\section{Hvordan kan begrepet sakprosa forstås?}

Som med de fleste humanvitenskapelige begreper og betegnelser må vi finne oss i at det ennå bare 70 år gamle ordet 'sakprosa' dekker en rekke forskjelligartede fenomener. Sakprosa har ofte ulike referanser i forskjellige sammenhenger. Ordet har sine særbetydninger innenfor skole, forlagsvesen, kulturpolitikk og massemedier. Men i den toneangivende nordiske sakprosaforskningen er det for det første enighet om at sakprosa ikke er et overhistorisk, stabilt fenomen, men et begrep som har oppstått på et bestemt tidspunkt for å gi en grunnleggende felles mening til tekster som ikke tilhører den skjønnlitterære institusjonen. For det andre er det enighet om at begrepet skal omfatte både litterær og funksjonell sakprosa. Det betyr at forskerne og studentene både beskjeftiger seg med litterære tekster, altså forfattersignerte tekster som gis ut av forlag eller tilsvarende institusjoner, og funksjonelle tekster, dvs. mer kollektivt-institusjonelle tekster som for eksempel produseres i utdanningsinstitusjonene, næringslivet, politikken og forvaltningen (Tønnesson 2009 s. 34). Sakprosaforskningen dekker derfor forskning om essayistikk og reiseskildringer så vel som næringslivets såkalte "mission statements" og regjeringens offentlige utredninger.

\section{Konteksten i teksten}

Hvordan forstå og analysere sakprosa? Et viktig begrep for å forstå sakprosaens egenart i ulike kontekster er "tekstkultur". Vi tilhører alle flere større og mindre tekstkulturer. En "tekstkultur" kan enkelt defineres som «en gruppe mennesker som samhandler gjennom tekster ut fra et noenlunde felles normsystem» (Tønnesson 2008:58, Berge 2002 og Asdal m.fl. 2008). Det som for eksempel kan oppfattes som en tekst i én tekstkultur, for eksempel en "tag" blant taggere $\mathrm{i}$ moderne storbyer, kan oppfattes som meningsløse skriblerier i en annen. Innenfor hver tekstkultur gjelder det spesielle konvensjoner, tekstnormer, som kvalifiserer hvilke ytringer som gjelder som tekster, og hvordan ytringene må være konstruert for å gi mening som tekst. Den medisinske forskningskulturen er en slik tekstkultur, med ganske strenge normer for hvordan man skal ytre seg, særlig i vitenskapelige publikasjoner (Berge 2007).

Vi vil i det følgende peke på noen dimensjoner ved kontekst som er relevante i de fleste sakprosastudier. 


\section{Materialiteten}

Et sentralt premiss for sakprosaforskningen er at tekst og kontekst ikke kan løsrives fra hverandre. Riktig nok kan en bok eller en trykket avisside finnes som et artefakt, altså som en materiell gjenstand som langt på vei kan bevares uforandret i tid og rom. Tilsynelatende er altså det som i dagligtalen kalles en tekst, for eksempel en artikkel i et nummer av Wergelands For Arbeiderklassen, noe stabilt som tåler tidens tann. Vi tenker ofte ikke over skillet mellom tekstens konkrete fremtredelsesform og dens mer abstrakte eller immaterielle karakter, tidsskriftartikkelen er "den samme" i 1839 som i 2009. I åndsverklovgivningen er det den immaterielle siden - fra disposisjon til ordlyd - som beskyttes. Men også det materielle bærer rik mening. La oss gjøre et raskt sprang og bruke avisnettsiden som illustrasjon på det sterkt dynamiske forholdet mellom tekst og "materiell" kontekst: Ikke nok med at den enkelte artikkelen kan se forskjellig ut fra den ene nettleseren til den andre, men omgivelsene på skjermbildet forandrer seg fra dag til dag, ofte fra sekund til sekund. Og vi kan selv legge inn våre kommentarer som med et tastetrykk blir en del av teksten. Ofte beskrives dette som en helt ny mediesituasjon. Men også de trykte medienes tekster preges uavlatelig av de omgivelsene og formatene de presenteres, og deres mening er ikke stabil. $^{3}$

\section{Kontekstens dynamiske karakter}

Denne innsikten deler sakprosaforskningen i høy grad med den nyere, etnografisk pregede samtaleanalyse-tradisjonen (Linell 2009). Her er det et ukontroversielt premiss at deltakerne i samtaler skaper konteksten mens de snakker og at de kan rekontekstualisere samtalen underveis. Samtaleforskerne har rett når de hevder at den skriftlige teksten gjerne er mer dekontekstualisert enn spontan-samtalen, men her er det kun tale om gradsforskjeller: Det er ikke lenger nok å studere den skriftlige sakprosateksten "i lys av" sin samtid og fortid, vi må søke forståelse av vekselspillet mellom disse og undersøke hvordan kontekstene skriver seg inn i teksten samtidig som tekstene skaper nye kontekster.

\section{Kontekstens nivåer}

Etymologisk er ordet kontekst satt sammen av latinsk "con" (sammen med) og "textus" (vev; tekst). Vi har slått fast at dette som virker sammen med teksten delvis finnes $\mathrm{i}$ teksten selv og at det er i stadig endring. Hvordan kan et så omfattende begrep som kontekst håndteres? Etnografen Malinowskis skille mellom en allmenn kulturkontekst og en mer spesifikk og avgrenset situasjonskontekst har vist seg slitesterkt. En tekst forstås best når vi både har øyne for situasjonene den opptrer i og dens større, normpregede sammenheng. Sammen med en mer eller mindre direkte utskilling av et tredje nivå - den tekstuelle eller intertekstuelle konteksten - utgjør skillet mellom kultur- og situasjonskontekst et viktig teoretisk utgangspunkt for store deler av sakprosaforskningen. Denne 
måten å operasjonalisere kontekstbegrepet på har fagfeltet for øvrig felles med både samtaleforskningen og hele den verdensomspennende, språkvitenskapelige tradisjonen som springer ut av Michael Hallidays systemisk-funksjonelle lingvistikk (SFL), herunder den kritiske diskursanalysen (CDA), som vi særlig forbinder med blant andre Norman Fairclough og Ruth Wodak (Fairclough 1995, Wodak 2009).

\section{Tekstens funksjoner og stemmer}

Nettopp den systemisk-funksjonelle lingvistikkens begrepsapparat gir en god hjelp for den som skal forstå sakprosatekstens sosiale forankring: Det er vanlig å legge betydelig vekt på tekstens parallelle funksjoner. Her finnes det mange forslag til inndeling, men skillet mellom en "ideasjonell" (av noen språkfilosofer forstått som "referensiell") funksjon og en mellompersonlig funksjon står sentralt langt utenfor de miljøene som bekjenner seg til SFL. Vi refererer til fenomener $\mathrm{i}$ verden og omskaper fenomenene $\mathrm{i}$ ett eller flere semiotiske systemer som ytringer. Disse ytringene bruker vi for å henvende oss til hverandre og for å strukturere relasjonene til den eller dem vi henvender oss til. Hallidays tredje funksjon er den tekstuelle funksjonen, som dreier seg om tekstens organisering - grammatisk og kompositorisk. ${ }^{4}$. Vårt poeng her er å understreke hvor sentralt funksjons-tenkningen står i sakprosaforskningen: Skal en tekst forstås i sin kontekst, må vi også ha blikk for dens latente og faktiske funksjoner og ta i betraktning at en ytring aldri kun har én funksjon.

Den ideasjonelle funksjonen har vi indirekte vært inne på $\mathrm{i}$ vår korte diskusjon av sakprosaens særskilte virkelighetstilknytning vis a vis skjønnlitteraturen. Denne språk- eller tekstfunksjonen har prinsipielt sett like stor interesse for begge: Enhver ytring, oppdiktet eller faktabasert, innebærer at det hevdes påstander om verden eller at en verden skapes, gjennom skapende performative språkhandlinger. Men selve begrepet sakprosa innbyr ofte til en særlig forståelse av den ideasjonelle funksjonen som tekstens evne til å henvise ut over ytringen, og dermed til tekstenes referanser til noe utenfor teksten. Hva er det saken gjelder, eller bedre: Hvordan konstrueres saken gjennom språket? Den mellompersonlige funksjonen gjelder samspillet mellom tekstens deltakere. Da snakker vi både om de deltakerne som omtales i teksten og de som skriver og leser den. I den nyere sakprosaforskningen har flere forskere vunnet ny og verdifull innsikt ved å identifisere og "lytte fram" disse deltakernes stemmer (Tønnesson 2001;2004). Identifiseringen av stemmene kan gi en rikere og mer fruktbar tekstanalyse (Veum og Raddum 2006). Stemmene kan dels være manifeste, altså ytringer fra navngitte personer gjennom sitater og henvisninger. Men når de ofte må lyttes fram, er det fordi mange deltakerstemmer er til stede på en implisitt måte, slik som når en lærebokforfatter vekselvis lar fagpersonen og pedagogen ha ordet i sin tekst. Også lesernes stemmer kan være foregrepet i teksten - ja, lesernes svarende reaksjoner er faktisk foregrepet i enhver ytring, hevder den store russiske litteraturforskeren Mikhail Bakhtin (1998). Dette 
innebærer ikke noen påstand om at ytringen automatisk genererer bestemte svar. Men ytringen inneholder potensielle, ofte parallelle, svarende reaksjoner som kan betraktes som "lesere-i-teksten", de som den såkalte resepsjonsestetikken har vært så opptatt fra 1970-årene og framover. I sakprosaforskningen er det særlig Umberto Ecos begrep "modelleseren" som har fătt gjennomslag (Eco 1979, Tønnesson 2004).

\section{Modalitet og multimodalitet}

I sakprosa er ofte forskjellen mellom "Det finnes", og "kanskje finnes det" eller "Du bør vurdere å stoppe" og "Stopp!" helt avgjørende for realiseringen av henholdsvis den ideasjonelle og den mellompersonlige funksjonen. ${ }^{5}$ Derfor står modalitet sentralt i mange sakprosaanalyser. Men akkurat som med stemmene i teksten, er det ikke alltid at de språklige uttrykkene kan tas for pålydende. Formal-grammatisk modalitet er ofte ikke det samme som ytringsmodalitet. I én situasjon kan nettopp "Du bør vurdere å stoppe" være en vel så effektiv stoppordre som den imperative varianten, og studier av vitenskapelig prosa har vist at forbeholdene ofte ikke er alvorlig ment: Uttrykket "There may be an X" er den konvensjonelt korrekte måten å uttrykke seg på, selv når man er helt sikker på at X finnes. Også i studiet av sakprosaytringens modalitet må vi dermed ta konteksten i betraktning.

Den modus vi velger - den måten vi omtaler saken på - er altså i høy grad med på å bestemme ytringens proposisjonelle innhold. Vi har et vidt modalitetsregister, en vifte av muligheter, å velge mellom hver gang vi formulerer oss. Mellom det positivt bombesikre ("Det finnes") til det negativt like sikre ("Det finnes ikke") finnes en skala: "Det må finnes", "Det finnes muligens", "Det finnes neppe" osv. Mange foretrekker å skille begrepsmessig mellom slik modalitet og modalitet i den forstand vi bruker ordet når vi snakker om multimodalitet. Her gjelder mulighetsvalgene for eksempel grotesk eller antikvaskrift, verbaltekst eller bilde, stillbilder eller levende bilder, stumfilm eller lydfilm. Lenge ble mye tekst- og litteraturforskning drevet som om tekster kun bestod av verbaltekst. Til nød kunne man uttale seg om samspillet mellom slik tekst og "illustrasjonene". Men den etter hvert intense forskningen om teksters multimodalitet har gjort at vi ikke lenger kan godta at ikke-verbale tegn nødvendigvis spiller annenfiolin. Hva som illustrerer hva, varierer både med tekst og kontekst. For at fagområdet ikke skal bli for diffust, foreslås det i $\mathrm{Hva}$ er sakprosa å la sakprosabegrepet omfatte tekst hvor det verbale spiller en hovedrolle (Tønnesson 2008 s. 34). Men ingen sakprosaforskning kan lenger ignorere det multimodale som preger enhver tekst.

Her er sakprosaforskningen alliert med den tendensen i litteraturforskning som ofte kalles "bokhistorie". Denne retningen gjelder imidlertid både fortidige og samtidige tekster, og den omfatter langt flere medier enn bøker. Også her insisteres det på at tekstenes materielle uttrykk er viktig, ofte avgjørende, for deres betydning (Rem 2003; Finkelstein og McCleery (red.) 2006; Asdal m.fl. 
2008). Bokhistorien er igjen ganske nært beslektet med en blomstrende forskningstradisjon med "literacy" eller skriftkyndighet som hovedoverskrift. Literacyforskeren undersøker ofte nettopp et mangfold av sakprosatekster historisk og samtidig - i de ulike situasjoner de blir brukt. Der både klassiske filologer og moderne litteraturvitere søker det unike, har imidlertid literacyforskeren en særlig forkjærlighet for den funksjonelle sakprosaen i det alminnelige hverdagslivet (Barton og Hamilton 1998; Mjelve 2001, Karlsson. 2006). Det som gjør literacyforskningen særlig interessant, er at den forklarer utviklingen av skriftbaserte tekstkulturer. Uten skriften som redskap ville neppe avanserte tekstkulturer som vitenskap, rettssystem og byråkrati være mulig. Literacyforskningen bidrar derfor til at vi forstår samfunnsbærende sosiale institusjoner som tekstkulturer der sakprosa utvikles og kultiveres (Goody 1986).

\section{Retorikkens relevans}

Semiotikk, funksjonell lingvistikk, bakhtinsk dialogisme, bokhistorisk litteraturforskning. Vi har allerede nevnt nærmere et dusin fagdisipliner som sakprosaforskningen har trukket inn i sin virksomhet. Betyr dette at man praktiserer en eklektisme uten teoretisk stringens og epistemologisk forankring? Som sentrale forskere innen feltet vil vi selvsagt ikke svare ja på dette. Vi deltok begge $\mathrm{i}$ formuleringen av de tekstteoretiske tesene som vi foreslo som program for Prosjektmiljøet Norsk sakprosa (Berge 2001 s. 61-62). Her foretas de avgrensningene vi i en litt annen form har gjentatt ovenfor: Mot essensialisme, mot dekontekstualisert objektivisme og mot formalgrammatikk, formalstilistikk og monomodal tekstforståelse, for å nevne noen litt mer militante slagord. Sakprosaforskningen kan imidlertid ikke - og ønsker ikke - å bygge én koherent og totaliserende teori. Innenfor de grenser som her er nevnt, bør forskningen være åpen og inviterende mot både nye og eldre tradisjoner i vitenskapen.

En i særklasse gammel tradisjon er retorikken, som også sakprosaforskningen begjærlig har øst av. Nesten like gammel som denne overbevisningens vitenskap er diskusjonen om hvor vidt dens virkefelt bør være: Skal den kun omfatte visse former for muntlig, offentlig tale med overbevisning som mål, eller gjelder den det overtalende, persuasive, trekket $\mathrm{i}$ alle slags ytringer muntlige, skriftlige, verbale og ikke-verbale? (Kjeldsen 2006) Her tar ikke vi noe standpunkt, men nøyer oss med å trekke fram noen nøkkelbegreper fra retorikken som mange sakprosaforskere vil oppleve som uunnværlige.

Triaden etos, logos og patos - retorikkens klassiske "bevismidler" - har fellestrekk med de tekstfunksjonene vi kort har presentert, men er ikke identiske med dem. Særlig etos og logos dreier seg om de trekk ved teksten og situasjonen som er egnet til å styrke tilliten til taleren - herunder det som kan kalles talereni-teksten: Uten tillit blir ingen overbevisning skapt. Men en taler, forfatter eller journalist som er uten kunnskaper om sitt emne eller ute av stand til å formidle 
dem i en logisk sammenheng, vil ganske fort miste den tillit som er forsøkt skapt gjennom etos-byggende øvelser.

Samtidig minner retorikken oss om at følelser, og altså bruken av bevismidlet patos, langt fra behøver å gjøre sakprosaen patetisk. Patos appellerer for det første til de allmenne forestillinger som publikum holder som rimelige og sanne, altså til doxa. For det andre er en følelsesløs tekst lite egnet til kommunikasjon, langt mindre til overbevisning. «Känslouttryck äro principielt uteslutna», skrev sakprosabegrepets far, Rolf Pipping, idet han unnfanget begrepet (Pipping1938). Dermed tilførte han barnet en fødselsskade som det ennå ikke er kommet helt over: ideen om at saklighet innebærer emosjonell frakopling, hva nå det er. For Pipping dreide det seg nok om et stilistisk saklighetsideal $\mathrm{i}$ opposisjon til det svulstige og forførende i hans samtid. Men en tekst som er helt fri for patos vil trolig være uleselig.

Den metaforiske ideen om at retorisk arbeid er en vandring - $i$ en hage eller $i$ et større landskap - innebærer at både tekstskaperen og leseren forholder seg til mer eller mindre kjente steder - topoi. Et slikt sted, en slik topos, kan for eksempel kan være et fast uttrykk ("Bare det beste er godt nok"), en ny vri på uttrykket ("Godt nok er ikke nok") eller en fast forestilling (for eksempel om at det høye er bedre enn det lave). Mange sakprosaforskere har vunnet ny innsikt gjennom både teorien om bevismidlene og ved å bruke topos-begrepet (jf. Tønnesson 2004).

Endelig er det fremdeles retorikken som danner hovedgrunnlaget for vår forståelse av argumentasjon. Aristoteles skilte, slik vi fremdeles bør skille, mellom logiske bevis og hverdagslig sannsynlighetsargumentasjon. I en del nyretorikk har argumentasjonslæren blitt videreutviklet til stive og kontekstufølsomme dogmer om gyldig og ugyldig argumentasjon. Men ved å kombinere argumentasjonslære med den antikke retorikkens begrep om kairos, om den retoriske eller argumentative situasjonen, kan retorikken fortsatt være ytterst anvendelig for sakprosaforskeren: Igjen er kontekstens tilstedeværelse i teksten en gyllen nøkkel.

\section{Estetikken}

Når "estetikk" ikke er et hyppig forekommende ord i nyere sakprosastudier, skyldes det kanskje mest at forskningen har vært opptatt av å bryte nytt land i en tid hvor mye humanistisk forskning var preget av "autonomiestetikk". Ideen om studieobjektets unike og gjerne tidløse kunstneriske kraft har den moderne kunstinstitusjonen som en selvsagt begrepsmessig ramme, noe sakprosaforskningen ikke har. Men la oss minne om at estetikk har med sansing å gjøre, gjerne med sansingens erkjennelse. Selvsagt er et prosadikt av Tor Ulven mer sanselig-estetisk enn en spalte $i$ en telefonkatalog. Men i studiene av det multimodale ved tekster kan vi vanskelig komme utenom spørsmål omkring hvordan ulike uttrykk taler til sansene. Tenker vi oss litt om, vil vi fort bli enige 
om at slike spørsmål er aktuelle for alle slags sakprosatekster, også de som tilsynelatende kun uttrykker knusktørr saklighet.

Her og nå vil tidsskriftet Sakprosa invitere forfattere, forskere og studenter til i høyere grad enn før å utforske sakprosaens estetiske kvaliteter, deskriptivt, men kanskje også normativt. Slik utforsking kan skje både gjennom retorikkens, lingvistikkens og semiotikkens begreper, men gjerne også inspirert av spesifikt estetisk teori.

\section{Hvorfor sakprosaforskning?}

Som et humanistisk fagområde - med forbindelseslinjer inn i en rekke andre vitenskapsområder - henter sakprosaforskningen sin berettigelse først og fremst gjennom å søke grunnleggende innsikter om forholdet mellom tekst og sak i det store universet som omfatter det meste av det som skrives utenfor det som vi til enhver tid $\mathrm{i}$ vårt samfunn oppfatter som tekster tilhørende den skjønnlitterære institusjonen. Hvilke tekster det er, vil alltid være gjenstand for debatt. Selvsagt er mange av dette universets tekster allerede gjenstand for omfattende forskning. Nettopp humanvitenskapen har alltid hatt tekster som sitt primære analyseområde. Ja, alle vitenskaper studerer hverandres tekster uopphørlig. Men der kjemikeren blander væsker og gasser i laboratoriet er de multimodale aktstykkene, oftest skriftlige tekster, humanistenes laboratoriemateriale. De fleste humanister er altså i en viss forstand sakprosaforskere, selv om historievitenskapen først og fremst søker å forstå hendelsesforløp, sosiale mønstre og årsakssammenhenger, mens sakprosaforskeren uavlatelig er opptatt av teksten om sakene. Men altså ikke nødvendigvis bare av tekstene "i seg selv"; tekstene skal leses i sin sammenheng, enten det er kulturen generelt eller situasjonen spesielt - og de skal leses i forhold til hvordan de forholder seg til virkeligheten: henvisende og/eller skapende. Sakprosaforskning er både en grunnleggende tekstvitenskap og en "saksvitenskap". Studiet av merkevarebyggende stillingsannonser, historievitenskapelige artikler, barnematmerking og naturfaglærebøker har begrenset verdi hvis forskeren står uten grundige kunnskaper om henholdsvis arbeidsliv, historie, barnemat og naturfag.

Sakprosaforskningens andre berettigelse hentes i dens potensielle nytteverdi. Det skapes mye kontraproduktiv sakprosa og allerede skapte sakprosatekster leses ofte på en lite fruktbar måte. Bevisstheten om dette har gitt en sterk økning av interessen for sakprosa og sakprosaforskning i skolen i Norden de siste årene. Denne lar seg lese ut av de siste læreplanene, av læremidlene og av skolens etterspørsel etter forskning og forskere. Også i mye annet arbeidsliv - i privat næringsliv, forvaltning, juss og politikk - ønsker mange å bli klokere på sakens prosa og ikke minst å skrive bedre tekster. Den litterære sakprosaen har trolig styrket sin stilling i Norden, men både i forlagene, avisredaksjonene og blant de kulturpolitiske myndighetene etterlyses kunnskap om disse tekstene og deres forhold til de sakene de tar for seg. 
Vi finner imidlertid ingen grunn til å anbefale et klassisk skille mellom grunnforskning og "anvendt forskning" innenfor vårt fagområde. Det stilles like høye vitenskapelige og teoretiske krav til artikkelen om en bruksanvisning som til det vitenskapelige essayet om et vitenskapelig essay. Selvsagt vil mange sakprosaforskere kunne utføre kortvarige oppdrag hvor de først og fremst anvender etablert teori og velprøvd teknikk, og gir oppdragsgiveren gode, praktiske råd. Sakprosa vil på sin side gjerne motta manuskripter til artikler som på en vitenskapelig måte reflekterer over slike studier og kritisk evaluerer forskerens råd.

\section{Virkelighetens tekster?}

Da det svenske sakprosaprosjektet skulle publisere eksempler på sine sakprosaanalyser, fikk boka tittelen Verklighetens texter (Melander \& Olsson, red. 2001). I en moderne tekstkultur preget av vitenskapelig tenkning i den europeiske opplysningstradisjonen er det rimelig å oppfatte det slik at et viktig skille mellom skjønnlitteraturens og sakprosatekstens leserkontrakter gjelder forholdet til virkeligheten. I de tekstkulturene hvor ordet "sakprosa" inngår i vokabularet, er det en alminnelig oppfatning at å lese tekster som sakprosa innebærer at tekstene anses som intensjonelt etterrettelige ytringer om de sakene den tar for seg, enten det gjelder frokostblandingens sammensetning, verdenskrigens årsaker eller teorien om språkspill. I Tønnessons definisjonsforslag i boka $H v a$ er sakprosa (2008, s. 34), som bygger på Claus Detlefs fra 20 år tidligere (Detlef 2008, s. 6), trekkes det et skille mellom direkte og indirekte ytringer om virkeligheten: «Sakprosa er tekster som adressaten har grunn til å oppfatte som direkte ytringer om virkeligheten.» Implisitt hevdes det altså her at fiksjon i vår tekstkultur er å anse som en "indirekte" vei til virkeligheten - at virkelighetstilknytningen her er indirekte.

Definisjonsforslaget ble introdusert slik:

Når vi definerer et kulturelt skapt fenomen som sakprosa, bør vi være forsiktige med å gi vesensdefinisjoner, altså definisjoner som oppfattes som forsøk på å gripe en grunnleggende essens ved fenomenet, kanskje på tvers av tid og rom. Definisjonene bør være praktiske, for de skal utrette et arbeid for oss i de tekstkulturene vi opptrer i til daglig. Samtidig skal de bidra til å utvikle disse tekstkulturene.

(ibid. s. 32)

Alle med innsikt i språk- og tegnvitenskap vil se det problematiske med definisjonen dersom den skulle oppfattes som universell: Nettopp forholdet mellom språket og virkeligheten er for komplisert til noen sinne å kunne kalles direkte. For eksempel slipper vi aldri unna metaforiske trekk ved språket, altså slike trekk som henter bilder fra ett betydningsområde og overfører det til et annet (Lakoff \& Johnson 1980; Svanlund 2001). Også semiotikkens innsikter om forholdet mellom tegn, tegnbærer og det betegnede vaksinerer mot en banal korrespondanseteori der språket og teksten er et slags "speilbilde" av virkeligheten (Eco 1975). 
Men hvilket "arbeid" er det så denne praktiske definisjonen likevel kan utrette? Her er et eksempel: Vi kan tenke oss at en historisk skolert og belest forfatter ønsker å skrive enda en bok om Annen verdenskrig. Ambisjonen er å utvide leserens innsikt $\mathrm{i}$ visse sider av denne krigen og eventuelt trekke linjer fram til dagens samfunn. Denne forfatteren kan grunnleggende sett velge mellom å skrive en historisk roman og en faghistorisk framstilling. I det første tilfellet har leseren god grunn til å vente seg at teksten sier noe om den historiske virkeligheten på en indirekte måte - at den altså går veien om en fiksjon. Veien behøver ikke være noen omvei i den forstand at den gir mindre innsikt, den tilbyr bare innsikt på et annet plan. Fiksjonen kan selvsagt inneholde mange dokumenterbare innslag, uten at disse endrer den grunnleggende fiksjons-kontrakten.

Dersom forfatteren derimot velger å gi en faghistorisk framstilling - bred eller smal - har leseren rett til å forvente at påstander om historiske hendelser og sammenhenger er dokumentert, eller at forfatteren presiserer det dersom hun kommer med påstander som ikke lar seg dokumentere. På den annen side må hun og han gi teksten en eller annen dramaturgi slik at den blir leselig. Teksten er altså en konstruksjon, men ingen fiksjon. For 20 år siden ville det være nødvendig å argumentere grundig og nøyaktig for berettigelsen av et grunnleggende skille mellom en faghistorisk framstilling og en roman som vesensforskjellige leserkontrakter. Da var det akademisk mote å hevde at det var like mye diktning i den historiske doktoravhandlingen som i romanen om samme emne. Poststrukturalismen har utvilsomt lært oss mye om sakprosaens upålitelighet og karakter av konstruksjon. Men heller ikke poststrukturalismen har etter vår oppfatning for alvor rokket ved det grunnleggende behovet $\mathrm{i}$ vår tekstkultur for å skille mellom fiksjonens og sakprosaens leserkontrakter. Det kan vi blant annet iaktta gjennom de mange debattene om bøker som bevisst lokaliseres i grenselandet - fra Per Olov Enquists Legionärerna (1968) til Peter Fröberg Idlings Pol Pots leende og Karl Ove Knausgaards påbegynte seksbindsverk Min kamp (2008).

Begrepet "sakprosa" kan bidra til å skape økt klarhet i slike debatter, uansett om man ønsker å befeste eller myke opp grenselinjene. Vårt tidsskrift hilser selvsagt bidrag skrevet ut fra begge disse posisjonene velkommen. I sin anmeldelse av Hva er sakprosa i Svenska dagbladet (28.8.2008) går den svensknorske litteraturprofessoren Arne Melberg i rette med definisjonsforslaget under overskriften «Ny litteratur passar inte in i gamla genrer». Vi tolker ikke hans kritikk som en avvisning av sakprosabegrepets berettigelse. 


\section{Litteratur}

Asdal, Kristin, Kjell Lars Berge, Karen Gammelgaard, Trygve Riiser Gundersen, Helge Jordheim, Tore Rem og Johan L. Tønnesson 2008: Tekst og historie. A lese tekster historisk, Oslo: Universitetsforlaget

Bakhtin, Mikhail M. 1998 (1953-54): Spørsmålet om talegenrane. Bergen: Ariadne

Berge, Kjell Lars 2001: «Det vitenskapelige studiet av sakprosa. Om tekstvitenskapelige utfordringer og løsninger i norsk og svensk sakprosaforskning» i Berge m.fl. 2001: Fire blikk på sakprosaen. Oslo: Prosjektmiljøet Norsk sakprosa, skrift nr 1, INL, Universitetet i Oslo, s. 9-74. Finnes digitalt her: http://sakprosabloggen.no/skriftserien/

Berge, Kjell Lars 2002: «Teksthistorie» i Berge (red.): Teksthistorie - tekstvitenskapelige bidrag, Oslo: Prosjektmiljøet Norsk sakprosa, skrift nr 1, INL, Universitetet i Oslo, s. 520.

Berge, Kjell Lars 2007. "The Rhetoric of Science in Practice: Experiences from Nordic Research on Subject-Oriented Texts and Text Cultures.” I: K. Fløttum (ed.) Language and Discipline Perspectives on Academic Discourse. Cambridge Scholars Publishing

David Barton and Mary Hamilton 1998: Local literacies. Reading and writing in one community, London: Routledge

Detlef, Claus 1988: Bogen om sagprosa. København: Dansklærerforeningen

Eco, Umberto 1976: A theory of semiotics, Bloomington: Indiana University Press

Eco, Umberto 1979: The role of the reader, Explorations in the semiotics of texts. London: Hutchinson

B. Englund \& P. Ledin (red.) 2003: Teoretiska perspektiv på sakprosa. Lund: Studentlitteratur Enquist, Per Olov 1968: Legionärerna. Stockholm: Norstedt

Eriksen, Trond Berg 1995: Nordmenns nistepakke. En kritikk av den norske kanon (Oslo: Cappelen)

Eriksen, Trond Berg og Egil Børre Johnsen 1998a: Norsk litteraturhistorie. Sakprosa fra 1750 til 1995. Bind I. Oslo: Universitetsforlaget

Eriksen, Trond Berg og Egil Børre Johnsen 1998b: Norsk litteraturhistorie. Sakprosa fra 1750 til 1995. Bind II. Oslo: Universitetsforlaget

Fairclough, Norman 1995: Critical discourse analysis : the critical study of language, Harlow: Longman

Finkelstein, David and Alistair McCleery (red.) 2006: The Book history reader. London: Routledge .

Goody, Jack. 1986. The Logic of Writing and the Organization of Society. Cambridge: Cambrigde UP:

Grepstad, Ottar 1997: Det littercere skattkammer. Sakprosaens teori og retorikk. Oslo: Det norske samlaget

Idling, Peter Fröberg 2006: Pol Pots leende. Om en svensk resa genom röda khmerernas Kambodja. Stockholm: Atlas

Johnsen, Egil Børre (red.) 1995: Virkelighetens forvaltere. Norsk Sakprosa. Første bok. Oslo: Universitetsforlaget

Johnsen, Egil Børre (red.) 1996: Forbildets forbilder. Norsk Sakprosa. Andre bok. Oslo: Universitetsforlaget

Johnsen, Egil Børre (red.) 1997: Tekstens mellommenn. Norsk Sakprosa. Tredje bok. Oslo: Universitetsforlaget

Karlsson, Ann-Malin 2006: En arbetsdag i skriftsamhället. Stockholm: Norstedts

Kjeldsen, Jens Elmelund 2006: Retorikk $i$ vår tid. En innføring $i$ moderne retorisk teori, Oslo: Spartacus

Knausgaard, Karl Ove 2008: Min kamp. 1. Oslo: Oktober 
Lakoff, George og Mark Johnson 1980: Metaphors we live by. Chicago : University of Chicago Press

Linell, Per 2009: Rethinking language, mind, and world dialogically : interactional and contextual theories of human sense-making, Charlotte, N.C. : Information Age Publications

Melve, Leidulf 2001: Med ordet som våpen. Tale og skrift $i$ vestleg historie, Oslo: Samlaget

Melander, Björn \& Björn Olsson (red.) 2001: Verklighetens texter. Sjutton fallstudier, Lund: Studentlitteratur

Maagerø, Eva 2005: Språket som mening. Innføring i funksjonell lingvistikk for studenter og loerere, Oslo: Universitetsforlaget

Pipping, Rolf 1938: «Språk och stil» i Finsk tidskrift nr 10, 1938, s. 272

Rem, Tore (red.) 2003: Bokhistorie. Oslo: Gyldendal

Svanlund, Jan 2001: Metaforen som konvention: graden av bildlighet $i$ svenskans vikt- och tyngdmetaforer, Stockholm: Stockholm studies in Scandinavian philology

Svensson, Jan, Olle Josephson \& Staffan Selander 1996: Svensk sakprosa - en projektbeskrivning. Lund: Institutionen för nordiska språk, Rapporter från Svensk sakprosa nr 1

Svennevig, Jan 2009: Språklig samhandling : innføring i kommunikasjonsteori og diskursanalyse, Oslo: Cappelen akademisk

Tønnesson, Johan L. 2001: Vitenskapens stemmer. Vitenskapsbilder, dialogisme og forskernoerver i fire historiefaglige tekster for allmennheten. Oslo: Prosjektmiljøet Norsk sakprosa, skrift nr 1, INL, Universitetet i Oslo. Finnes digitalt her: http://sakprosabloggen.no/skriftserien/

Tønnesson, Johan L. 2004: Tekst som partitur eller Historievitenskap som kommunikasjon, Oslo: Unipub

Tønnesson, Johan L. 2008: Hva er sakprosa. Oslo: Universitetsforlaget

Veum, Aslaug og Tonje Raddum (2006): «Avistekstens mange stemmer», Norsk medietidsskrift 2/2006

Veum, Aslaug 2008: Avisas andlet: førstesida som tekst og diskurs: Dagbladet 1925-1995, Oslo: Unipub

Wodak, Ruth 2009: The discourse of politics in action: politics as usual, Basingstoke: Palgrave Macmillan

\footnotetext{
${ }^{1}$ Prosjektet Svensk sakprosa 1750-2000 ga ut i alt 32 rapporter på forlaget Studentlitteratur i Lund. 19 av disse er (per august 2009) digitalisert og finnes (uten illustrasjoner) på nettsiden http://www.studentlitteratur.se/o.o.i.s/329.

${ }^{2}$ Prosjektmiljøet Norsk sakprosa ga i perioden 2001-2004 ut i alt 10 bøker i en egen skriftserie. Samtlige (med unntak av én enkelt artikkel) er digitalisert og finnes på nettsiden http://sakprosabloggen.no/skriftserien/.

${ }^{3}$ Se nærmere om dette i Asdal m.fl. 2008.

${ }^{4}$ En glimrende redegjørelse for Hallidays tekstfunksjoner finnes i Veum 2008.

${ }^{5}$ En god introduksjon til modalitet (i SFL-tradisjonen) finnes i Maagerø 2005.
} 